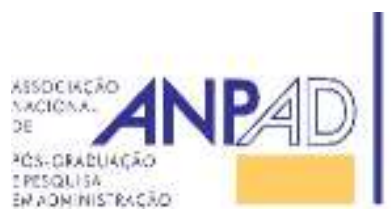

Available online at http://www.anpad.org.br/bar

BAR, Rio de Janeiro, v. 13, n. 1, art. 1, pp. 1-18, Jan./Mar. 2016

\title{
Relationships and Partnerships in Small Companies: Strengthening the Business through External Agents
} Antonio Luiz Rocha Dacorso ${ }^{2}$ Vanessa Barreto Costa ${ }^{3}$ Luiz Carlos Di Serio ${ }^{3}$

Universidade Federal de Alagoas ${ }^{1}$

Universidade Federal de Sergipe ${ }^{2}$ Fundação Getulio Vargas - Escola de Administração de Empresas de São Paulo ${ }^{3}$ 


\begin{abstract}
This article aims to understand the relationships between small companies and external innovation agents and how they can help strengthening these organisations. A multiple case research method was adopted by the researchers and applied to small companies which presented innovative practices. The data collection included documents, records and interviews with managers/business owners. Such interviews were recorded and coded using the NVivo 10 software. The results showed relationships of trust, partnership and learning. The article contributes to the idea that small companies recognize the importance of external knowledge sources in their business and innovation strategies. Companies believe in these relationships in order to bring essential competencies to their business, and continuously renovate themselves through shared feedback. This in turn leads to the capture of financial and technological resources as well as market and competitive information that strengthens the business and allows it to overcome its limitations.
\end{abstract}

Key words: relationships; partnerships; external knowledge sources; open innovation; small business. 


\section{Introduction}

Small companies now account for a significant part of the economy (Nakano, 2010), representing almost $99 \%$ of all companies operating in Brazil (Greco, 2013). Although their share of the market has increased, these companies have experienced difficulties keeping a competitive innovation strategy, in part due to their limited structural and financial capacity to assume inherent risks in the decision to innovate (Bianchi, Campodall'Orto, Frattini, \& Vercesi, 2010). In virtue of this, many innovations are adopted far too late by these firms and only after clear and safer opportunities demonstrate their potential in the market, or when pressure exists in the business environment to adopt them (Parida, Westerberg, \& Frishammar, 2012).

This happens because the traditional model of innovation dictates that innovation is achieved through the internal competencies of the organisation (Lindegaard, 2011), which is difficult for small companies to achieve due to their particular features (Grapeggia, Lezana, Ortigara, \& Santos, 2011). This situation affects the longevity of these companies in the market, knowing that innovation is a stepping stone to increase performance and competitive advantage (Crossan \& Apaydin, 2009; Schumpeter, 1982; Smith, Busi, Ball, \& Meer, 2008; Vargas, 2015).

Gassmann, Enkel and Chesbrough (2010), Ibarra, Rueda and Arenas (2015), Love and Roper (2015), Silva and Dacorso (2013a, 2013b, 2014a, 2014b) and Vanhaverbeke, Vermeersch and De Sutter (2012) argue that the open innovation model can assist the growth and development of small enterprises, as the utilization of external knowledge in the value chain of these small businesses can lead to cost reductions in research and development (R\&D) and increases in the capacity for organisational innovation.

The open innovation model consists of the use of external knowledge as a valuable font in the innovation process. It is based on organisations working together with the goal of sharing the necessary resources for their development (Chesbrough, 2012). Thus companies can strengthen the innovation process through capturing external resources as well as strengthening their own routines and internal organisational competencies (Pénin, Hussler, \& Burger-Helmchen, 2011).

Despite this, small companies are under-researched within open innovation literature, which concentrates mainly on large or high-end technology companies (Gassmann, Enkel, \& Chesbrough, 2010), and the results generated by these studies into open innovation are not easily applied to small companies, which exhibit differences when compared to large companies. This creates the need for specific studies which encompass the functionality of open innovation in the context of these organisations (Vanhaverbeke, Vermeersch, \& De Sutter, 2012).

In relation to the above, this article's objective is to understand how the relationship between the small enterprises and external innovation agents as defined by the open innovation model can help to strengthen these organisations.

The article is structured as follows. First we discuss the new perspectives that arise with the use of open innovation by small companies, and proceed to examine the challenges and obstacles faced by such companies. Then, the methodology section presents a description of the field work, comprising the elaboration of analytical categories, as well as data collection and analysis. Finally, we present the results of the case study that was conducted. 


\section{Relationships and Partnerships in the Business Environment: New Perspectives with the Use of Open Innovation}

Innovation takes place alongside developments in science and, according to the changing market demands, there is an evolution in the use of various sources of knowledge as an alternative development in the face of rapid changes (Fagerberg, Fosaas, \& Sapprasert, 2012). Pénin, Hussler and Burger-Helmchen (2011) and Chesbrough (2012) argued that companies previously kept internal knowledge as a form of competitive advantage, but this logic changed with the introduction of open innovation model, since then companies have started commercializing or sharing knowledge that was previously only for internal use.

Xia and Roper (2008), through a comparative study between American and European companies, affirmed there is a strong link between the capacity to innovate and the union of internal and external knowledge, resulting in the maximum usage of knowledge as an organisational competitive factor, so companies that use external knowledge tend to increase their internal capacity to innovate.

The open innovation model also favours the task of joining complementary technologies that become hybrids and profitable, which Wang (2012, p. 4) defines as "fusion of innovation". The author reveals that companies with dynamic capabilities in only one part of a process, product, or technology, can overcome their lack of capacity through partnerships with outside agents who have skills in these areas. This allows organisations to develop jointly, absorbing the necessary inputs for their survival from other organisations (Woerter \& Roper, 2010). As a consequence, companies reduce the risks and uncertainties that come with the acquisition of technologies, and make them more likely to launch new products and services (Kafouros \& Forsans, 2012).

However, for the open innovation model to add value to the organisation, it is important for them to establish routines that allow them to absorb and jointly develop internal and external capacities (Xia \& Roper, 2008). This occurs because the open innovation paradigm constitutes a radical innovation for the companies that adopt it, requiring changes to their entire organisational structure, in order to prepare the organisations to search for external knowledge (Christensen, Olesen, \& Kjaer, 2005).

Denotations show a tendency to use alliances and partnerships in the development of innovations (Gassmann et al., 2010). Clausen, Pohjola, Sappraserty and Verspagen (2011) identified that the creation of innovation strategies is based on three sources of information: (a) Science: universities, research institutes, patents, consultants and computer networks; (b) Industry: clients, suppliers, competitors, and internal sources; and (c) Opportunistic: equipment suppliers, magazines, professional conferences, fairs and shows.

The main motivation for the formation of partnerships is mutual learning, in a way that all partners look to gain knowledge which assists them to maximize innovation towards their organisational performance (Xia \& Roper, 2008). Nevertheless, the function of external knowledge sources within organisations is to create ideas that serve as a basis for innovation, helping to produce various alternatives that can be converted to value-adding solutions and opportunities for the business (Gallon, Ensslin, \& Silveira, 2009).

\section{Operation of Small Companies in the Market: Challenges and Obstacles Faced}

In order for the organisation to become competitive through innovation, the company needs to consider not only the innovation process itself, but also to consider the factors that permit innovation management as holistic and interconnected elements (Smith et al., 2008). An innovative organisation 
is one that innovates systematically and can maintain an appropriated model of innovation (Crossan \& Apaydin, 2009; Smith et al., 2008; Tang, 1998) which considers specific factors that increase its capacity for innovation (Hurley \& Hult, 1998; Lawson \& Samson, 2001; Teece, Pisano, \& Shuen, 1997).

In the case of small enterprises, Jong and Marsili (2006) identified certain variables as being important in the capacity to innovate: (a) innovation inputs: practices and activities aimed at innovation; (b) innovation sources and powers acquired to innovate; (c) management attitude: ability to manage innovation processes or practices; (d) planning of innovation: developing strategies and innovative formats; (e) external orientation: market vision and cooperation; and (f) innovation outputs: generated products, processes and services.

This format is due to the high cost of $R \& D$, which makes these companies innovate through the use of informal innovation practices (Forsman, 2011; Hirsch-Kreinsen, 2008; Santamaría, Nieto, \& Barge-Gil, 2009). Allied to this, small companies do not have sufficient resources to expand their operations and invest in innovations (Esteves \& Nohara, 2011). One of the alternatives available to small enterprises is cooperation via searching for support amongst public and private institutions, aiming to strengthen their own structures and competitive mechanisms (Maçaneiro \& Cherobim, 2011).

Franco and Haase (2010) argue that small companies need to have characteristics that create competitive advantages. This can be achieved through the use of external knowledge (Parida et al., 2012; Silva \& Dacorso, 2013a, 2013b, 2014a, 2014b). Vanhaverbeke et al. (2012) also point out that small companies are more confident about the use of the open innovation model than large companies. The studies developed by Silva and Dacorso (2013a, 2013b, 2014a, 2014b) also show positive results from the use of external knowledge sources in the innovation process of small enterprises, which have the potential to provide the most competitive performances for such organisations and also to serve and support the development of significant innovations for the businesses.

A study carried out by Van De Vrande, Jong, Vanhaverbeke and Rochemont (2009) identified that small companies used Open Innovation of inputs and outputs. In the first case there is the search and acquisition of external knowledge for the organisation which, when interacting with external agents, generates innovations more dynamically and faster than in an isolated form. In the second case, the knowledge from the technologies and processes belonging to the organisation, generated through use of the model, is commercialized and sold as a product or passed on to the market.

The input to open innovation practices found in small companies studied by Van De Vrande et al. (2009) are: involvement of customers (97\%); use of networks in innovation processes (94\%); involvement of employees (93\%); outsourcing of R\&D (50\%); participation in other firms (32\%); and intellectual property licensing from other firms $(20 \%)$. The output of open innovation practices are: operation of businesses (29\%); and licensing of intellectual property to other companies (10\%).

Other studies have also demonstrated the importance of external sources of knowledge in these companies. Rammer, Czarnitzki and Spielkamp (2009) showed that 57\% of small enterprises considered innovative use external sources of knowledge. Gassmann et al. (2010) showed that small companies can adopt the open innovation model as a business model. Vanhaverbeke et al. (2012) argue that even small low-technology enterprises have demonstrated successful use and integration of external sources of knowledge in the creation and development of innovations. Thus, small businesses demonstrate using the logic of the open innovation model in the management process and use of resources.

Silva and Dacorso (2013a) tried to establish a link between the difficulties faced by small businesses and the open innovation model, which appears as an ideal innovation model for such companies, because it allows the companies to address such difficulties in an effective way. Based on such findings, Silva and Dacorso (2014a) also found that the innovative small companies maintain an innovation processed built on the precepts of the open innovation model. Similar conclusions may be 
found in the international literature on the subject, so we argue that the phenomenon extrapolates local realities and represents aspects that may be found in small companies across different localities.

In the following section, we discuss the methodological aspects that guided the field work during the empirical phase of the research.

\section{Methodology}

This study is qualitative in nature with its purpose classified as being exploratory and descriptive (Bryman \& Bell, 2011; Neuman, 1997; Saunders, Lewis, \& Thornill, 2000). The research strategy used was multiple case study, which provided a better understanding of the elements that were still unclear in the relationship between the sources of external knowledge, present in the open innovation model, and small enterprises, while at the same time showing how this relationship works (Eisenhardt, 1989; Yin, 2001).

In order to look for patterns, establish dimensions or categories and analyse the phenomenon under multiple lenses, multiple cases were undertaken (Eisenhardt, 1989) in six small enterprises, with the aim of launching theoretical generalizations that can contribute to the current literature (Eisenhardt, 1989; Yin, 2001).

We chose to adopt Yin's guidelines for case study research. Therefore, the study was conducted based on a case study protocol (Yin, 2001), with the following steps: (a) choice of companies that made up the study; (b) scheduling of interviews with the managers; (c) conducting a pilot case with one of the selected companies; (d) description and analysis of information in the test case; (e) suitability script for carrying out semi-structured interviews; (f) carry out interviews and collect documents and records; (g) description of function in cases of established analytical categories; (h) preparation of the interim report of each case; (i) analysis of documents and records of the companies; (j) analysis of the information from the interviews, records and documents; (k) triangulation and crosscase analysis; and (1) the final report.

The companies were chosen based on the following criteria: companies who fit the category of being a small business according to Serviço Brasileiro de Apoio às Micro e Pequenas Empresas (SEBRAE, 2011); had practices, activities or a processes of innovation, which had been awarded by SEBRAE as competitive; and being affiliated with SEBRAE. SEBRAE is a non-profit technical institution, formed jointly by the Brazilian government and the private sector, focused on programs for promoting and strengthening small enterprises in Brazil. Therefore it is considered an external innovation agent.

Interviews were scheduled with managers/owners of the small businesses. Interviews lasted an average of 1 hour, and were recorded and later transcribed. Two researchers proceeded to analyze the raw data and code it with NVivo, in a way that each category and element of analysis (Table 1) became nodes and sub-nodes in software, organized in hierarchical fashion. This allowed the researchers to cope with the "deluge of data" (Eisenhardt, 1989, p. 9), by transforming the raw data into structured and easy to retrieve information. Documents and records were also used as evidence sources, examples of such documents include web pages, business reports, press releases and promotional materials, for each company. The documents were used as part of a triangulation strategy and to verify the types of innovations, as well as which fonts had been accessed by the studied companies. A pilot interview was conducted on Alpha Company for validation of the semi-structured interview guide. After transcription, interviews were analysed individually, followed by cross-case analysis and triangulation of the interviews, records and documents (Eisenhardt, 1989), based on the categories and elements of analysis (Table 1) that directed the study. 
Table 1

\section{Categories and Elements of Analysis}

\begin{tabular}{|c|c|}
\hline Categories & Elements of analysis \\
\hline $\begin{array}{l}\text { External sources of } \\
\text { knowledge }\end{array}$ & $\begin{array}{l}\text { - External sources of knowledge accessed: universities, government, competitors, } \\
\text { customers, suppliers, other companies, R \& D centers, laboratories, supporting } \\
\text { agencies, incubators and fairs, events and conferences (Chesbrough, 2012; } \\
\text { Lindegaard, 2011); } \\
\text { - Intended results: financial, technological, market, and competitive resources } \\
\text { (Chesbrough, 2012; Lindegaard, 2011). }\end{array}$ \\
\hline $\begin{array}{l}\text { Aspects observed in the } \\
\text { relationship between } \\
\text { companies and external } \\
\text { sources of knowledge }\end{array}$ & $\begin{array}{l}\text { - External sources of knowledge used (Chesbrough, 2012; Lindegaard, 2011; Parida et } \\
\text { al., 2012); } \\
\text { - Role of the open innovation model in the organisation (Dahlander \& Gann, 2010); } \\
\text { - Open innovation type: input; output (Chesbrough, 2012; Lindegaard, 2011); } \\
\text { - Impact: radical; incremental (Parida et al., 2012); } \\
\text { - Established relationships: trust; partnership; learning (Clausen, Pohjola, Sappraserty, } \\
\text { \& Verspagen, 2011; Silva \& Dacorso, 2014a) } \\
\text { - External Knowledge: Complementary; replacement (Wang, 2012); } \\
\text { - Learning Type: episodic; relational; through the client (Forsman, 2011); } \\
\text { - Results achieved (Chesbrough, 2012; Lindegaard, 2011). }\end{array}$ \\
\hline
\end{tabular}

Note. Source: Elaborated by the authors based in literature review.

\section{Presentation and Discussion of Cases and Results}

Next, we present the characteristics of the companies studied (Table 2), the external sources of Knowledge accessed (Table 3), and the aspects observed in the relationship between companies and external sources of Knowledge (Table 4). 
Table 2

\section{Characteristics of the Companies Studied}

\begin{tabular}{|c|c|c|c|c|c|c|}
\hline & Alpha & Beta & Gamma & Delta & Epsilon & Zeta \\
\hline $\begin{array}{l}\text { Number of } \\
\text { employees }\end{array}$ & 32 & 05 & 06 & 25 & 20 & 07 \\
\hline Years active & 20 years & 14 years & 13 years & 19 years & 29 years & 27 years \\
\hline Sector & Industrial & Commerce & Commerce & Services & Services & Services \\
\hline Segment & Metal fasteners & Orthodontic Implants & $\begin{array}{l}\text { Automation and } \\
\text { instrumentation }\end{array}$ & Gas & Naval services & $\begin{array}{l}\text { Automation and } \\
\text { instrumentation }\end{array}$ \\
\hline Principal product & Retaining screws & Orthodontic Implants & Electrical panels & Gas projects & maritime baskets & Pumps \\
\hline Performance level & National & State & National & International & National & Local \\
\hline Entrance barriers & $\begin{array}{l}\text { Techniques and know } \\
\text { how }\end{array}$ & $\begin{array}{l}\text { Financial and know } \\
\text { how }\end{array}$ & $\begin{array}{l}\text { Techniques and use of } \\
\text { Chinese products }\end{array}$ & $\begin{array}{l}\text { Know how and } \\
\text { credibility }\end{array}$ & $\begin{array}{l}\text { Technical and } \\
\text { diversification }\end{array}$ & $\begin{array}{l}\text { Techniques, know how, } \\
\text { financial }\end{array}$ \\
\hline Difficulties faced & $\begin{array}{l}\text { Financial, technological, } \\
\text { market and competitive. }\end{array}$ & $\begin{array}{l}\text { Financial, } \\
\text { technological, market } \\
\text { and competitive. }\end{array}$ & $\begin{array}{l}\text { Financial, } \\
\text { technological, market } \\
\text { and competitive. }\end{array}$ & $\begin{array}{l}\text { Financial, } \\
\text { technological, market } \\
\text { and competitive. }\end{array}$ & $\begin{array}{l}\text { Financial, } \\
\text { technological, market } \\
\text { and competitive. }\end{array}$ & $\begin{array}{l}\text { Financial, } \\
\text { technological, market } \\
\text { and competitive. }\end{array}$ \\
\hline
\end{tabular}

Note. Source: Field research (2015). 
Table 3

\section{External Sources of Knowledge Accessed}

\begin{tabular}{|c|c|c|c|c|c|c|}
\hline & Alpha & Beta & Gamma & Delta & Epsilon & Zeta \\
\hline $\begin{array}{l}\text { External } \\
\text { sources of } \\
\text { knowledge } \\
\text { accessed }\end{array}$ & $\begin{array}{l}\text { Clients, suppliers, } \\
\text { competitors, other } \\
\text { companies, supporting } \\
\text { bodies, fairs, events, } \\
\text { conferences and } \\
\text { laboratories. }\end{array}$ & $\begin{array}{l}\text { Clients, suppliers, } \\
\text { competitors, other } \\
\text { companies, supporting } \\
\text { bodies, fairs, events, } \\
\text { conferences. }\end{array}$ & $\begin{array}{l}\text { Clients, suppliers, } \\
\text { competitors, other } \\
\text { companies, supporting } \\
\text { bodies, universities, fairs, } \\
\text { events, conferences. }\end{array}$ & $\begin{array}{l}\text { Clients, suppliers, } \\
\text { competitors, other } \\
\text { companies, supporting } \\
\text { bodies, universities, } \\
\text { fairs, events, } \\
\text { conferences. }\end{array}$ & $\begin{array}{l}\text { Clients, suppliers, } \\
\text { competitors, other } \\
\text { companies, supporting } \\
\text { bodies, universities, } \\
\text { fairs, events, } \\
\text { conferences. }\end{array}$ & $\begin{array}{l}\text { Clients, Government, } \\
\text { Suppliers, universities, } \\
\text { investors, companies, } \\
\text { fairs, events, } \\
\text { conferences, } \\
\text { laboratories, } \\
\text { supporting bodies. }\end{array}$ \\
\hline $\begin{array}{l}\text { Intended } \\
\text { Results }\end{array}$ & $\begin{array}{l}\text { Financial, technological, } \\
\text { market and competitive } \\
\text { resources. }\end{array}$ & $\begin{array}{l}\text { Financial, } \\
\text { technological, market } \\
\text { and competitive } \\
\text { resources. }\end{array}$ & $\begin{array}{l}\text { Financial, technological, } \\
\text { market and competitive } \\
\text { resources. }\end{array}$ & $\begin{array}{l}\text { Financial, technological, } \\
\text { market and competitive } \\
\text { resources. }\end{array}$ & $\begin{array}{l}\text { Financial, } \\
\text { technological, market } \\
\text { and competitive } \\
\text { resources. }\end{array}$ & $\begin{array}{l}\text { Financial, } \\
\text { technological, market } \\
\text { and competitive } \\
\text { resources. }\end{array}$ \\
\hline
\end{tabular}

Note. Source: Field research (2015).

Table 4

\section{Aspects Observed in the Relationships between Companies and External Sources of Knowledge}

\begin{tabular}{|c|c|c|c|c|c|c|}
\hline & Alpha & Beta & Gamma & Delta & Epsilon & Zeta \\
\hline $\begin{array}{l}\text { External sources } \\
\text { of knowledge } \\
\text { accessed }\end{array}$ & $\begin{array}{l}\text { Clients, suppliers, } \\
\text { competitors, other } \\
\text { companies, supporting } \\
\text { bodies, fairs, events, } \\
\text { conferences and } \\
\text { laboratories. }\end{array}$ & $\begin{array}{l}\text { Clients, suppliers, } \\
\text { competitors, other } \\
\text { companies, supporting } \\
\text { bodies, fairs, events, } \\
\text { conferences. }\end{array}$ & $\begin{array}{l}\text { Clients, suppliers, } \\
\text { competitors, other } \\
\text { companies, supporting } \\
\text { bodies, universities, } \\
\text { fairs, events, } \\
\text { conferences. }\end{array}$ & $\begin{array}{l}\text { Clients, suppliers, } \\
\text { competitors, other } \\
\text { companies, } \\
\text { supporting bodies, } \\
\text { universities, fairs, } \\
\text { events, conferences. }\end{array}$ & $\begin{array}{l}\text { Clients, suppliers, } \\
\text { competitors, other } \\
\text { companies, supporting } \\
\text { bodies, universities, } \\
\text { fairs, events, } \\
\text { conferences. }\end{array}$ & $\begin{array}{l}\text { Clients, Government, } \\
\text { Suppliers, universities, } \\
\text { investors, companies, fairs, } \\
\text { events, conferences, } \\
\text { laboratories, supporting } \\
\text { bodies. }\end{array}$ \\
\hline
\end{tabular}

Continues 
Table 4 (continued)

\begin{tabular}{|c|c|c|c|c|c|c|}
\hline & Alpha & Beta & Gamma & Delta & Epsilon & Zeta \\
\hline $\begin{array}{l}\text { Role of the open } \\
\text { innovation model }\end{array}$ & Business model & Business model & Business model & Business model & Business model & Business model \\
\hline $\begin{array}{l}\text { Type of open } \\
\text { innovation }\end{array}$ & $\begin{array}{l}\text { Of non-monetary input } \\
\text { and revealing output }\end{array}$ & $\begin{array}{l}\text { Of non-monetary input } \\
\text { and revealing output }\end{array}$ & Of non-monetary input & $\begin{array}{l}\text { Of non-monetary } \\
\text { input }\end{array}$ & Of non-monetary input & Of non-monetary input \\
\hline Impact & Radical & Incremental & Incremental & Incremental & Incremental & Radical \\
\hline $\begin{array}{l}\text { Type of relationships } \\
\text { established }\end{array}$ & $\begin{array}{l}\text { Trust, partnership and } \\
\text { learning }\end{array}$ & $\begin{array}{l}\text { Trust, partnership and } \\
\text { learning }\end{array}$ & $\begin{array}{l}\text { Trust, partnership and } \\
\text { learning }\end{array}$ & $\begin{array}{l}\text { Trust, partnership and } \\
\text { learning }\end{array}$ & $\begin{array}{l}\text { Trust, partnership and } \\
\text { learning }\end{array}$ & $\begin{array}{l}\text { Partnership and } \\
\text { learning }\end{array}$ \\
\hline External Knowledge & $\begin{array}{l}\text { Substitute for the } \\
\text { innovation process }\end{array}$ & $\begin{array}{l}\text { Substitute for the } \\
\text { innovation process }\end{array}$ & $\begin{array}{l}\text { Substitute for the } \\
\text { innovation process }\end{array}$ & $\begin{array}{l}\text { Substitute for the } \\
\text { innovation process }\end{array}$ & $\begin{array}{l}\text { Substitute for the } \\
\text { innovation process }\end{array}$ & $\begin{array}{l}\text { Substitute for the } \\
\text { innovation process }\end{array}$ \\
\hline Type of learning & $\begin{array}{l}\text { Episodic, relational and } \\
\text { through the client }\end{array}$ & $\begin{array}{l}\text { Episodic, relational and } \\
\text { through the client }\end{array}$ & $\begin{array}{l}\text { Episodic, relational and } \\
\text { through the client }\end{array}$ & $\begin{array}{l}\text { Episodic, relational } \\
\text { and through the client }\end{array}$ & $\begin{array}{l}\text { Episodic, relational and } \\
\text { through the client }\end{array}$ & $\begin{array}{l}\text { Episodic, relational and } \\
\text { through the client }\end{array}$ \\
\hline Results achieved & $\begin{array}{l}\text { Competitiveness; new } \\
\text { markets; value creation; } \\
\text { reduction of risks and } \\
\text { uncertainties; financial, } \\
\text { technological, market } \\
\text { and competitive } \\
\text { resources. }\end{array}$ & $\begin{array}{l}\text { Competitiveness; new } \\
\text { processes and products; } \\
\text { value creation; } \\
\text { reduction of risks and } \\
\text { uncertainties; financial, } \\
\text { technological, market } \\
\text { and competitive } \\
\text { resources. }\end{array}$ & $\begin{array}{l}\text { Competitiveness; new } \\
\text { products and processes; } \\
\text { value creation; } \\
\text { reduction of risks and } \\
\text { uncertainties; financial, } \\
\text { technological, market } \\
\text { and competitive } \\
\text { resources. }\end{array}$ & $\begin{array}{l}\text { Competitiveness; new } \\
\text { markets and raw } \\
\text { materials; value } \\
\text { creation; reduce } \\
\text { uncertainty; financial, } \\
\text { technological, market } \\
\text { and competitive } \\
\text { resources. }\end{array}$ & $\begin{array}{l}\text { Competitiveness; new } \\
\text { procedures and } \\
\text { processes; value } \\
\text { creation; reduction of } \\
\text { risks and uncertainties; } \\
\text { financial, } \\
\text { technological, market } \\
\text { and competitive } \\
\text { resources. }\end{array}$ & $\begin{array}{l}\text { Competitiveness; new } \\
\text { products; new sector; } \\
\text { value creation; } \\
\text { reduction of risks and } \\
\text { uncertainties. }\end{array}$ \\
\hline
\end{tabular}

Note. Source: Field research (2015). 
By default, companies stayed in contact with customers and suppliers as sources for external knowledge by modifying their practices and improving business through daily feedback with these agents. Companies Alpha and Beta kept this relationship format with customers and suppliers, whereas companies Delta and Epsilon only kept it with customers. All companies also counted on employees in this process. Access to these sources is due to the case of small companies, customers and suppliers being the main sources of creative ideas, as well as employees, who are in direct contact with these customers and should be involved in all stages of the innovation process (Alsaaty, 2011).

Companies Gamma and Zeta had a different and adverse behaviour between them. From the beginning of their activities, Gamma's activities maintained a positive vision for the proximity of competitors, suppliers and customers as partners in their business strategies. This is related to the way in which the company started, since contact with the university, being open to other companies, and the manager's vision, have always been considered important to the sharing of knowledge between companies:

"No one owns the knowledge; it is good to share information and knowledge, nobody owns it and I think that is what is good. Today you can see people walking on their own two feet, developing their solutions. It's a rewarding thing" (Gamma).

Zeta was established without relying on any external source of knowledge, since the company's initial activities were of secondary importance for the manager. After contacting an external agent, the owner achieved the base knowledge necessary to reopen the company with another activity.

All companies analysed in this research have accessed various sources of knowledge in order to gain the required skills they needed to stay active when faced with situations where they had to review their competitive strategies, change their way of reacting to the market or its processes, or finding ways to survive:

"could not compete with the people who sold to us and we were not able to compete with our supplier, it was then that we realized that the company was no longer competitive (Alpha). There comes a time you feel the need to professionalize, you get to have a range of market demands and do not know what it will do. ... start to not know how to answer here and you begin to realize that if you do not answer you can lose, then you need to go back to become more professionalized" (Epsilon).

The search for alternatives in the face of market changes that these companies faced is explained by Vanhaverbeke et al. (2012), who argues that the limitations faced by small companies make it necessary to form a partnership with external sources of knowledge, so that when they modify their global strategy it is unlikely that small companies consider their strategies in relationships with external partners. Moreover, according to Van De Vrande et al. (2009), in terms of the acquisition and use of external technologies, small companies are proving increasingly open to the capture of external resources and interaction with various sources of knowledge, since they need to deal with the lack of both resources to innovate.

In the case of the Alpha Company, they foresaw their existence becoming uncertain, with the option of closing their doors or seeking an alternative for survival. Zeta resumed its activities through using external sources of knowledge, which served and remains as a basis supporting the performance of its activities. Beta, Delta and Epsilon sought external sources as a way to adapt to new market demands and gain skills to improve their competitiveness. Gamma was established with a culture focused on the inclusion of such sources in their daily practices.

The standard sources of external knowledge used by companies in this research are: customers, suppliers, competitors, other companies, support agencies and trade shows, events and conferences. Zeta was the only company analysed that does not contact competitors. As this company is involved in projects regarding patents that cannot be revealed to the market, there is a lot of suspicion about relationships between the company and its competitors. 
The results envisaged by these companies who seek out sources of external knowledge are financial, technological, and competitive market resources that would allow them to overcome their limitations of being small businesses. This scenario is shown by Heger and Rohrbeck (2012), who observed that the new environment configuration requires companies to better cater to changes that develop around them in order to reset their relationships with partners and regroup in order to acquire the necessary skills to cope with such changes.

It can be stated that the relationships between the small companies and external knowledge sources are based on trust, partnership and learning. These companies recognize the importance of external knowledge sources to their business and innovation strategies, trust in these relationships to achieve core competencies to their business and regenerate themselves through exchanged feedback. Zeta demonstrated that they maintain partnerships and learning relationships, but not reliability, since dealing with patent development involves suspicion as to the level of trust that must be maintained with the agents with whom they communicate. These findings correspond to reports by Rezende, Lima and Versiani (2012), who claim that relationships are the basis for the acquisition of all forms of knowledge.

The use of external knowledge sources was shown to replace the innovation process in all studied companies, which corroborates the findings of Hagedoorn and Wang (2012). Their study showed that companies with large investments in internal $R \& D$ tend to use external $R \& D$ complementarily, while companies that invest less in this type of knowledge tend to replace it with external R\&D.

The companies studied demonstrated learning through episodic learning, relational learning and through the client, so they learnt to solve everyday problems and exchanged experiences with external sources of knowledge through the daily communication they have with the client, respectively. This is in agreement with the claims of Pénin et al. (2011), who states that the paradigm of open innovation emerges as a new format to capture a sustainable way to spread knowledge in the environment and turn it into a way of learning and achieving mutual benefits. Thus, organisations have extended their business vision and incorporated external capacities by identifying and exploring the potential market in a better way, which for Roper and Arvanitis (2012) is a positive factor, since the value chain of innovation should be the acquisition, transformation and exploitation of knowledge in order to be effective.

All companies demonstrated use of the open innovation model and the business model adopted in those companies is such that strategies are formulated to support the use of external sources of knowledge. This result corresponds to the findings of Vanhaverbeke et al. (2012) which discussed that the use of the open innovation model in small companies has a different role from that observed in large companies. According to these authors, the adopted business models for these small businesses are vital to their development. This is in contrast to large companies, the result of which lies in the technologies they use. Therefore, while not having a large enough skilled workforce, small companies create business models which allow them to generate value through technology or obtain knowledge belonging to other companies by developing together.

All companies also showed open innovation with non-pecuniary input, which means without direct expenditure of funds for the acquisition of external knowledge, as shown by Dahlander and Gann (2010). Alpha and Beta companies demonstrated a revealing open innovation in their output process, as they transferred part of their knowledge to competitors, without receiving direct compensation, sales of patent or intellectual property. This result corresponds to the open innovation rating given by Dahlander and Gann (2010), who claim that in this format benefits are indirect, characterized by a better market image and the ability to attract new partners to form the company's strategies.

When it comes to the impact of the open innovation model in these companies, only Alpha and Zeta could be considered to have adopted a radical open innovation model, given that in both companies there was a significant change in the companies, characterized by change in an area of the 
business and a review of all business strategies, which started to deal with quite different activities carried out previously. In Alpha company the manufacturing of the fixing bolt changed from trade to industry. Zeta was reopened as an instrumentation company and developer of its patents.

It should be noted that this analysis is related to the radical nature of the open innovation model as business model, even though the open innovation model brings promising possibilities for development and improvement. Such possibilities may be an increased level of existing capabilities and the absorption of capabilities that support the new parameters within the boundaries already established by the company, as demonstrated in other companies whose open innovation model was characterized as an incremental innovation.

This line of thinking is supported by Robertson, Casali and Jacobson (2012) who pointed out that a critical point of differentiation is the impact of radical and incremental innovation on the organisation or in the market. Radical innovations represent a major shift in skills and technical knowledge and is incremental, where transformation happens at the level of the product subsystem or modified process.

Although the results are inherent to the degree of impact of the open innovation model in small companies, the companies are in disagreement with the assumptions made by Christensen, Olesen and Kjae (2005), who suggest the open innovation paradigm brings radical innovation for companies that adopt it. We can see a fine line between radical and incremental innovation in adopting the open innovation model in these companies, given that the use of external knowledge sources can result in combinations that require a higher or lower level of organisational change, so that, although the use of the model has been presented as an incremental innovation, there is the potential for radical innovation in these companies.

\section{Final Considerations}

The article sought to understand the relationship between small companies and external innovation agents, arising from the open innovation model and how it can help strengthen these organisations. For this, we used multiple case studies involving six small businesses.

The results showed that the relationship between external agents and small enterprises allow these organisations to master skills that allows them to overcome challenges and obstacles imposed on them by the competitive environment, which would otherwise be difficult to overcome in isolation. The search for external expertise makes these organisations use the open innovation model and business model, which then becomes part of the overall strategy of the organisation and redefines the way these companies see themselves and their market.

The cooperation fostered by open innovation increases the innovation performance of these companies, leading to increased competitive strength, making it easier to obtain financial, technological, market and competitive resources that add value to the businesses. As the external knowledge sources are the base of the model, the dynamics of the relationships between small companies and these sources are crucial to the competitive strengthening of these organisations, which demonstrates a relationship of trust and partnership favourable to the exchange of knowledge and information.

The outcomes of the contact between external sources of knowledge and the companies studied, suggest that the open innovation model provides the small companies with opportunities to develop themselves and their processes, with product and service innovations. This promotes a change in the strategic base of these enterprises, which now incorporate the use of external knowledge sources into their innovation activities. It is a model sought by these companies to overcome the difficulties and barriers they face to survive in the market. It requires a change of vision to those involved in the company who must recognize the sources of external knowledge driving development. Finally, 
innovation is a new parameter to these organisations. All these aspects allow small companies to strengthen their businesses through the use of external knowledge sources, providing them with a way to better compete in the market and an additional tool to assist in the innovation process.

Such results suggest that, even though there is a focus on larger enterprises as the object of study in previous open innovation research, the model is compatible with small companies as well. This points to a need to reassess the direction of current research, to extend the study of open innovation to different business contexts.

\section{Contributions and Suggestions for Future Research}

This study contributes to future research by demonstrating some patterns of how sources of external knowledge interact with small enterprises. These can aid the construction of theoretical bases that allow the use of a framework for these enterprises using the open innovation model and demonstrates how to generate value to the business. These organisations end up using the open innovation model as a business model, which can lead to an understanding of how these companies can compete better in the market.

This contribution highlights what seems to be a mismatch between the open innovation theory and small companies, since the open innovation model has no theoretically applicable framework in the context of these companies and other such endeavours use the model successfully.

As a practical contribution, the study enables these small companies to see themselves as a viable competitive model and can provide them with a more solid basis to develop. Additionally, the article draws attention to the importance of how these companies work together towards achieving better results.

Furthermore, we hope that the results of this study may contribute and serve as reference in the formulation of public policies on entrepreneurship in Brazil, especially those related to the innovation policies focused on small businesses. To consider the external sources of knowledge in the innovation process of these companies may contribute to the formulation of more adequate policies for small businesses.

For future research, we suggest developing a tool for checking the degree of open innovation in small companies, in order to determine to what extent these companies use external sources of knowledge in their innovation process, and their ability to generate innovation through these external sources. In addition, other studies should focus on the relationship between small companies and sources of external knowledge.

\section{References}

Alsaaty, F. M. (2011). A model for building innovation capabilities in small entrepreneurial firms. Academy of Entrepreneurship Journal, 17(1), 1-21.

Bianchi, M., Campodall'Orto, S. C., Frattini, F., \& Vercesi, P. (2010). Enabling open innovation in small and medium sized enterprises: how to find alternative applications for your technologies. $R \& D$ Management, 40(4), 414-431. doi: 10.1111/j.1467-9310.2010.00613.x

Bryman, A., \& Bell, E. (2011). Business research methods (3rd ed.). New York: Oxford University Press. 
Chesbrough, H. (2012). Inovação aberta: como criar e lucrar com a tecnologia. Porto Alegre, RS: Bookman.

Christensen, J. F., Olesen, M. H., \& Kjaer, J. S. (2005). The industrial dynamics of open innovation: evidence from the transformation of consumer electronics. Research Policy, 34(10), 1533-1549. doi: 10.1016/j.respol.2005.07.002

Clausen, T., Pohjola, M., Sappraserty, K., \& Verspagen, B. (2011). Innovation strategies as a source of persistent innovation. Industrial and Corporate Change, 21(3), 553-585. doi: 10.1093/icc/dtr051

Crossan, M. M., \& Apaydin, M. (2009). A multi-dimensional framework of organizational innovation: a systematic review of the literature. Journal of Management Studies, 47(6), 1154-1191. doi: 10.1111/j.1467-6486.2009.00880.x

Dahlander, L., \& Gann, D. M. (2010). How open is innovation? Research Policy, 39(6), 699-709. doi: 10.1016/j.respol.2010.01.013

Eisenhardt, K. M. (1989). Building theories from case study research. Academy of Management, 14(4), 532-550. doi: 10.5465/AMR.1989.4308385

Esteves, G., \& Nohara, J. J. (2011). Fatores críticos à estabilidade das alianças estratégicas das micro e pequenas empresas. Revista de Administração e Inovação, 8(3), 182-204. doi: 10.5773/rai.v8i3.863

Fagerberg, J., Fosaas, M., \& Sapprasert, K. (2012). Innovation: exploring the knowledge base. Research Policy, 41(7), 1132-1153. doi: 10.1016/j.respol.2012.03.008

Forsman, H. (2011). Innovation capacity and innovation development in small enterprises: a comparison between the manufacturing and service sectors. Research Policy, 40(5), 739-750. doi: 10.1016/j.respol.2011.02.003

Franco, M., \& Haase, H. (2010). Failure factors in small and medium-sized enterprises: qualitative study from an attributional perspective. International Entrepreneurship and Management Journal, 6(4), 503-521. doi: 10.1007/s11365-009-0124-5

Gallon, A. V., Ensslin, S. R., \& Silveira, A. (2009). Rede de relacionamentos em pequenas empresas de base tecnológica (EBTS) incubadas: um estudo da sua importância para o desempenho organizacional na percepção dos empreendedores. Journal of Information Systems and Technology Management, 6(3), 551-572. doi: 10.4301/S1807-17752009000300009

Gassmann, O., Enkel, E., \& Chesbrough, H. (2010). The future of open innovation. $R \& D$ Management, 40(3), 213-221. doi: 10.1111/j.1467-9310.2010.00605.x

Grapeggia, M., Lezana, A. G. R., Ortigara, A. Â., \& Santos, P. C. F. (2011). Fatores condicionantes de sucesso e/ou mortalidade de micro e pequenas empresas em Santa Catarina. Produção, 21(3), 444-455. doi: 10.1590/S0103-65132011005000025

Greco, S. M. de S. S. (Coord.). (2013). Global entrepreneurship monitor. Empreendedorismo no Brasil: 2013. Curitiba, PR: IBQP. Retrieved from http://www.ibqp.org.br/upload/tiny_mce/GEM_2013_-

_Livro_Empreendedorismo_no_Brasil.pdf

Hagedoorn, J., \& Wang, N. (2012). Is there complementarity or substitutability between internal and external R\&D strategies? Research Policy, 41(6), 1072-1083. doi: 10.1016/j.respol.2012.02.012 
Heger, T., \& Rohrbeck, R. (2012). Strategic foresight for collaborative exploration of new business fields. Technological Forecasting \& Social Change, 79(5), 819-831. doi: 10.1016/j.techfore.2011.11.003

Hirsch-Kreinsen, H. (2008). Low-tech innovations. Industry and Innovation, 15(1), 19-43. doi: $10.1080 / 13662710701850691$

Hurley, R. F., \& Hult, G. T. M. (1998). Innovation, market orientation, and organizational learning: an integration and empirical examination. Journal of Marketing, 62(3), 42-54. doi: $10.2307 / 1251742$

Ibarra, E. R. B., Rueda, J. A. C., \& Arenas, A. P. L. (2015). Mapping of the challenges for the open innovation model's implementation in service sector. Journal of Advanced Management Science, 3(4), 354-361. doi: 10.12720/joams.3.4.354-361

Jong, J. P. J., \& Marsili, O. (2006). The fruit flies of innovations: a taxonomy of innovative small firms. Research Policy, 35(2), 213-229. doi: 10.1016/j.respol.2005.09.007

Kafouros, M. I., \& Forsans, N. (2012). The role of open innovation in emerging economies: do companies profit from the scientific knowledge of others? Journal of World Business, 47(3), 362-370. doi: 10.1016/j.jwb.2011.05.004

Lawson, B., \& Samson, D. (2001). Developing innovation capability in organizations: a dynamic capabilities approach. International Journal of Innovation Management, 5(3), 377-400. doi: $10.1142 / \mathrm{S} 1363919601000427$

Lindegaard, S. (2011). A revolução da inovação aberta: princípios básicos, obstáculos e habilidades de liderança. São Paulo, SP: Évora.

Love, J. H., \& Roper, S. (2015). SME innovation, exporting and growth: a review of existing evidence. International Small Business Journal, 33(1), 28-48. doi: 10.1177/0266242614550190

Maçaneiro, M. B., \& Cherobim, A. P. M. S. (2011). Fontes de financiamento à inovação: incentivos e óbices às micro e pequenas empresas - estudo de casos múltiplos no estado do Paraná. Organizações \& Sociedade, 18(56), 57-75. doi: 10.1590/S1984-92302011000100003

Nakano, D. (2010). A produção independente e a desverticalização da cadeia produtiva da música. Gestão \& Produção, 17(3), 627-638. doi: 10.1590/S0104-530X2010000300015

Neuman, L. W. (1997). Social research methods: qualitative and quantitative approaches (3rd ed.). Boston: Allyn \& Bacon.

Parida, V., Westerberg, M., \& Frishammar, J. (2012). Inbound open innovation activities in high-tech SMEs: the impact on innovation performance. Journal of Small Business Management, 50(2), 283-309. doi: 10.1111/j.1540-627X.2012.00354.x

Pénin, J., Hussler, C., \& Burger-Helmchen, T. (2011). New shapes and new stakes: a portrait of open innovation as a promising phenomenon. Journal of Innovation Economics, 1(7), 11-29. doi: 10.3917/jie.007.0011

Rammer, C., Czarnitzki, D., \& Spielkamp, A. (2009). Innovation successof non-R\&D-performers: substituting technology by management in SMEs. Small Business Economics, 33(1), 35-58. doi: $10.1007 / \mathrm{s} 11187-009-9185-7$

Rezende, S. F. L., Lima, W. M. A., \& Versiani, Â. F. (2012). Evolução de conhecimentos no relacionamento comprador-fornecedor. Revista de Administração Contemporânea, 16(1), 39-58. Retrieved from http://www.scielo.br/pdf/rac/v16n1/a04v16n1.pdf. doi: 10.1590/S141565552012000100004 
Robertson, P. L., Casali, G. L., \& Jacobson, D. (2012). Managing open incremental process innovation: absorptive capacity and distributed learning. Research Policy, 41(5), 822-832. doi: 10.1016/j.respol.2012.02.008

Roper, S., \& Arvanitis, S. (2012). From knowledge to added value: a comparative, panel-data analysis of the innovation value chain in Irish and Swiss manufacturing firms. Research Policy, 41(6), 1093-1106. doi: 10.1016/j.respol.2012.03.002

Santamaría, L., Nieto, M. J., \& Barge-Gil, A. (2009). Beyond formal R\&D: taking advantage of other sources of innovation in low- and medium-technology industries. Research Policy, 38(3), $507-$ 517. doi: 10.1016/j.respol.2008.10.004

Saunders, M., Lewis, P., \& Thornill, A. (2000). Research methods for business students (2nd ed.). Harlow, England: Pearson Education.

Schumpeter, J. (1982). A teoria do desenvolvimento econômico: uma investigação sobre lucros, capital, crédito, juro e o ciclo econômico. São Paulo, SP: Ed. Abril S.A. Cultural e Industrial.

Serviço Brasileiro de Apoio às Micro e Pequenas Empresas. (2011). Anuário do trabalho na micro e pequena empresa: 2010-2011 (4a ed.). Retrieved from http://www.sebrae.com.br/Sebrae/Portal\%20Sebrae/Anexos/Anuario\%20do\%20Trabalho\%20N a\%20Micro\%20e\%20Pequena\%20Empresa_2010_2011.pdf

Silva, G., \& Dacorso, A. L. R. (2013a). Inovação aberta como uma vantagem competitiva para a micro e pequena empresa. Revista de Administração e Inovação, 10(3), 251-268. doi: 10.5773/rai.v10i3.1036

Silva, G., \& Dacorso, A. L. R. (2013b). Perspectivas de inovação na micro e pequena empresa. Revista Economia \& Gestão, 13(33), 90-107. doi: 10.5752/P.1984-6606.2013V13N33P90

Silva, G., \& Dacorso, A. L. R. (2014a). Processo de inovação na micro e pequena empresa: implicações e achados em empresas sergipanas. Revista Pensamento Contemporâneo em Administração, 8(3), 55-70. doi: 10.12712/rpca.v8i3.365

Silva, G., \& Dacorso, A. L. R. (2014b). Riscos e incertezas na decisão de inovar das micro e pequenas empresas. Revista de Administração Mackenzie, 15(4), 229-255. doi: 10.1590/167869712014/administracao.v15n4p229-255

Smith, M., Busi, M., Ball, P., \& Meer, R. V. D. (2008). Factors influencing an organization's ability to manage innovation: a structured literature review and conceptual model. International Journal of Innovation Management, 12(4), 655-676. doi: 10.1142/S1363919608002138

Tang, H. K. (1998). An integrative model of innovation in organizations. Technovation, 18(5), 297309. doi: 10.1016/S0166-4972(98)00009-1

Teece, D. J., Pisano, G., \& Shuen, A. (1997). Dynamic capabilities and strategic management. Strategic Management Journal, 18(7), 509-533. doi: 10.1002/(SICI)10970266(199708)18:7<509::AID-SMJ882>3.0.CO;2-Z

Van De Vrande, V., Jong, J. P. J., Vanhaverbeke, W., \& Rochemont, M. (2009). Open innovation in SMEs: trends, motives and management challenges. Technovation, 29(6/7), 423-437. doi: 10.1016/j.technovation.2008.10.001

Vanhaverbeke, W., Vermeersch, S., \& De Sutter, S. (2012). Open innovation in SMEs: how can small companies and start-ups benefit from open innovation strategies? Flanders: Vlerick Leuven Gent Management School. 
Vargas, M. I. R. (2015). Determinant factors for small business to achieve innovation, high performance and competitiveness: organizational learning and leadership style. Procedia Social and Behavioral Sciences, 169, 43-52. doi: 10.1016/j.sbspro.2015.01.284

Wang, M. (2012). Exploring potential R\&D collaborators with complementary technologies: the case of biosensors. Technological Forecasting \& Social Change, 79(5), 862-874. doi: 10.1016/j.techfore.2011.11.002

Woerter, M., \& Roper, S. (2010). Openness and innovation - home and export demand effects on manufacturing innovation: panel data evidence for Ireland and Switzerland. Research Policy, 39(1), 155-164. doi: 10.1016/j.respol.2009.09.007

Xia, T., \& Roper, S. (2008). From capability to connectivity - absorptive capacity and exploratory alliances in biopharmaceutical firms: a US-Europe comparison. Technovation, 28(11), 776-785. doi: 10.1016/j.technovation.2008.03.007

Yin, R. K. (2001). Estudo de caso: planejamento e métodos (2a ed.). Porto Alegre: Bookman.

\title{
Authors' Profiles
}

\author{
Glessia Silva \\ UFAL - Campus Sertão, Rodovia AL145, KM3, 3849, 57480-000, Delmiro Gouveia, AL, Brazil. E-mail address: \\ glessiasilva@hotmail.com \\ Antonio Luiz Rocha Dacorso \\ UFS - Campus Itabaiana, Rua Vereador Olímpio Grande s/n, 49500-000, Itabaiana, SE, Brazil. E-mail address: \\ antoniodacorso@gmail.com \\ Vanessa Barreto Costa \\ Av. 9 de Julho, 2029, 01313-902, São Paulo, SP, Brazil. E-mail address: vanessabarreto@ hotmail.com \\ Luiz Carlos Di Serio \\ Rua Itapeva, 474, 01332-000, São Paulo, SP, Brazil. E-mail address: luiz.diserio@fgv.br
}

